\title{
A study on parameters of online reviews content that influence consumers buying behaviour- an Indian perspective
}

\author{
Prashant Devedi \\ Area Head- Sales, Videocon d2h, Noida, India
}

R. Sujatha

Faculty of Human Resource Management and Organizational Behavior

Amity Business School, Amity University, Uttar Pradesh, India

Ruchi Pathak

Research Scholar, Amity International Business School

Amity University Uttar Pradesh, India

Key words

Online review, review content, buying behaviour

\begin{abstract}
The $21^{\text {st }}$ century customer is passionate about gaining knowledge. The availability and affordability of internet has created an edge for people to connect to a social network and exchange information. It has encouraged different online activities for consumers such as blogging, chatting, gaming, and messaging. The virtual space has helped this range of people involve to share posts or online reviews more quickly. Hence it is today believed online social networks are good platform for consumers to gather information and advice. All that a consumer shares as an opinion value add to the company's reputation. Reputation is viewed as an asset. This value can be damaged when a consumer share negative reviews. It reduces the brand image of a company that promises to deliver high-quality products.

The present study tries to fill the gap in the literature relating online product or service reviews in influencing the consumer buying behaviour. The objective of the study is to understand the parameters of review content on which consumer check online reviews before buying a product or service. To achieve the research objectives of the present study, a descriptive research design is used with primary data collection methodology through a structured questionnaire. The sample size for the study is 104. The analysis was conducted through mean, one sample t-test and correlations. The study identified that consumers view online reviews such as understanding quality of the product, product usage information, cost benefit of the product, information relevant to deals or discounts, and product information on warranty or guarantee or replacement details, Brand reputation among reviewers, Sales service availability for deciding to buy. It was observed that parameters of online review content influence the consumer's decision to buy.
\end{abstract}

Corresponding author: Ruchi Pathak

Email address for corresponding author: ruchigautampant@gmail.com

First submission received: 28th February 2017

Revised submission received: 18th March 2017

Accepted: 30th March 2017

\section{Introduction}

Globalisation has provided strategy of homogenization of markets. This has led to standardization of offerings to various markets. The differences in national tastes or modes of entering countries to do business are also disappearing. Such standardisation in offerings has pushed consumer expectations to a higher level. Consumer feels that there should be no disparity in 
price or quality of the product or service offered by organizations. This background context has created an opportunity for consumers with a wide spectrum of Brands to choose. Like change is constant, buying a product or service for an unsatisfied need by a consumer is also constant. Persistently consumers want to ensure that their buying decisions are right based on value and quality. Hence the consumer behaviour is a set cumulative activity of how individuals or groups of customer select, purchase, use and dispose ideas, goods or services to satisfy their needs and wants. This actions of a consumer is influenced by the attribution theory. The actions of the consumer in the market place and the motives are driven and dominated by personal and environmental factors.

The $21^{\text {st }}$ century customer is passionate about gaining knowledge. The availability and affordability of internet has created an edge for people to connect to a social network and exchange information. It has encouraged different online activities for consumers such as blogging, chatting, gaming, and messaging. For example, Facebook.com is one of the most popular social networking sites. Most of the Individuals account holders and members of Facebook can build in extraordinary personal profiles about themselves and continuously share information with members in the group. Increased Social interaction among friends and public per se, has emerged and created new set of behaviours which influence consumer's daily purchase decisions. Few factors that can have an influence on online consumers are family members, friends, co-workers, and group or individual. Individual loves to compare their decisions with others and seek best benefit in the choice of a product or service.

The virtual space has helped these ranges of people involve to share posts or online reviews more quickly. Hence it is today believed online social networks are good platform for consumers to gather information and advices. All that a consumer share as an opinion is a value add to the company's reputation. Reputation is viewed as an asset. This value can be damaged when a consumer share negative reviews. It finishes the brand image of a company that promises to deliver high-quality products. Few researchers call these opinions share in online reviews as e-sentiment information. This e-sentiment information is an indicator of business outcomes such as:

- Increasing of sales volume

- Declining sales

- Impact on market share

- Increasing product returns

- Increasing service cancellations

- Damaging the brand image and

- Decreasing value of products

However, there is a gap in the literature regarding perception of consumers on online reviews. The way the attributions are made by the consumer about online reviews can or need not affect their buying/purchasing decisions. The content of the review, a positive review or a negative review can be oversighted by a consumer whose perception about a review is obsolete. This study aims in closing such gaps.

\section{Review of Literature}

Most of the recent research studies identifies that consumer online review through various systems is widely used by consumers in facilitating their purchase decisions of product or services. The ecommerce has indeed created easier platform for exchange of product information by the companies to consumer and consumer's review to the organizations. These feedbacks nevertheless help company to bring in quality improvement and service modification. The online reviews on ecommerce impacts business by affecting or increasing profitability and purchase intentions. In the existing literature, there is not much of attention paid towards identifying the relationship between online reviews and the perception of consumers 'influenced by online review while deciding on prepurchase and purchase. 
A research study by Shih Yung Chou (2012) applies the theory of cognitive dissonance and develops a theoretical framework that analyses the relationships between online reviews and cognitive dissonance. The framework offered by this study may help increase the understanding of online consumer behaviour. The findings of this study reveal a positive impact of online reviews in the purchase decisions of product or service. Resnick et al (2000) identifies the role of e-commerce on global economy. It reveals the way retailers have sought to identify various approaches for improving their performance in the context of online markets. Online review systems are defined as platforms that collect, distribute, and aggregates feedback and comments about participants' past behaviour. Y. Chen and J. Xie (2008), online review and reputational management have received much attention by researchers and practitioners because of their potential impact on purchase decisions. The internet and the growth of social networking has become a major marketing platform for companies and retailers to attract customer attentions and visits to online site and reviews, $\mathrm{P}$. Chatterjee, (2000). P. J. Sher and S. Lee, (2009) in their research paper suggest online review systems have been suggested to be one of the most influential communication channels because online consumers can obtain information related to products and retailers. J. A. Chevalier and D. Mayzlin (2006) states that this characteristic has made online reviews as an important factor that influences sales volume and business growth. Sonnier, G.P., L. McAlister, O.J. Rutz(2011), also observed the influence of positive, negative, and neutral online communications on firm value. The findings report positive impact on stock returns of neutral buzz, but did not find any impact of positive and negative buzz.

Liu (2006) in a research study collected online posts from the Yahoo Movie message board. The messages/ reviews were coded. The valence of each post as positive, negative, or neutral was analysed. The findings reported impact of online buzz valence on dependent variable, i.e., weekly box office revenue. In comparison, more recent studies reported in a blog analyses that box office ticket sales of movies can be affected by the valence of online buzz information collected from Yahoo Movie and blog posts (Gopinath, Chintagunta, and Venkataraman, 2013).Chen, Stephen (2001) in the research work of assessing the impact of internet on brands claims that easy access to online customer reviews has led some audiences (consumers) to suggest that alternative assurances of product quality and performance. It includes findings such as brands will lose much of their importance in the interactive marketing environment. A research study by Bickart and Schindler (2001), proposes a new way of thinking to marketing strategies. The reasoning suggests that customers will detour marketer influenced signals like brands and instead rely directly on unfiltered e-word-of-mouth from other consumers. The information contained in such online reviews does not originate from the company, it is generally considered to be highly credible and influential. An Online customer reviews can be defined as peer-generated product evaluations posted on company or third party websites Mudambi \& Schuff (2010). Mostly it is the retail websites that offer consumers the opportunity to post product reviews with content of information related to quality, price comparisons, service offerings etc. it also promotes cumulative ratings of the product. These form of numerical star ratings (usually ranging from 1 to 5 stars) and open-ended customer-authored comments about the product. The Mudambi \& Schuff (2010) research study on online retailers such as Amazon.com highlight the way these sites have enabled consumers to submit product reviews for many years, with other retailers offering this option to consumers more recently. The case paper brings out how other firms choose to buy customer reviews from Amazon.com or other sites and post the reviews on their own electronic storefronts. In this way, the reviews themselves is a way to generate additional revenue stream for Amazon and other online retailers.

Kumar and Benbasat (2006) identifies the importance of messages or texts of customer reviews available on a website and its relationship in improving customer perception of the usefulness and social presence of the website. There are numerous advantages of the presence of online reviews in a website. It has the potential to attract consumer visits, increase the time spent on 
the site, and create a sense of community among frequent shoppers, but the focus shifts to the content of the review. It is a mechanism at the pre-stage purchase that the customer reviews lead to the evaluation of the product or service. Are all the reviews in an online reliable? A study by Dabholkar (2006) regarding online retailer's states that there are incentives provided for generating positive online reviews to retailers. Some sites therefore insist on the online content that customers perceive to be valuable, and sites such as e-opinions and Amazon.com post detailed guidelines for writing reviews. This is important as more researchers have claimed that website information positively affects consumers' attitudes toward shopping online (Jiang and Benbasat 2007).It is also observed in some research studies that the driving force of consumers to search online reviews are asymmetric information, lack of available information, increasing awareness, loyalty in the behaviour, product features, deals on product offerings etc. Online reviews can allow consumer perception on shopping sites and products to increase which enhances consumers to make better shopping decisions.

Few research studies discuss the credibility of online reviews. Most of the reviews are believed to be fake or company/retailers generated. Online reviews information is anonymous. There are lots of evidences in which it is found that information asymmetry is present in the websites and consumer online reviews. This confuses buying decisions of a consumer (Kumar and Benbasat, 2006). Studies highlight that reputation management practice encompasses various strategies that vary in their efficacy, and adherence to legal and ethical norms. These strategies range from outright review fraud (Luca and Zervas, 2015), to incentivizing consumers to leave reviews in exchange for perks, to taking legal action against consumers who leave negative reviews, and to using nondisparagement clauses in sales contracts that stipulate fines if consumers write negative reviews. an Mo, Yan-Fei Li, Peng Fan (2015) in their research work tries to understand the effect of online reviews on consumer purchase behaviour. The sample includes more than 400 Taobao shops' online reviews are collected. With the S-O-R model (Stimulus-Organism-Response Model), the research paper studies the influence on consumer purchase behaviour per online reviews of experience goods from a new perspective of consumer learning. The findings reveal that the positive reviews, describing rating, picture reviews, appended reviews and cumulative reviews influence consumer purchase behaviour. The paper also reflects the reputation behaviour that consumers cannot distinguish which transaction is fake, increasing judging difficulty per the comments. Further consumer learning refers to the process that consumers acquire knowledge and information to improve their buying behaviour constantly during the purchase. Consumers' attitudes are affected by the quantity and ratings of online reviews. When consumers want to purchase a good or service, they are influenced by the positive or negative comments/ online reviews, which in turn changes their buying decision. Better reviews strengthen the impulsive to buy a product.

\section{Objective of the study}

- To understand the parameters on which consumers use online reviews to make decisions for buying a product or service.

- To suggest companies to concentrate on certain important variables in managing the online review process.

\section{Research Methodology}

To achieve the research objectives of the present study, a descriptive research design is used with primary data collection methodology through a structured questionnaire with the reliability value of 0.887 . The entire universe that access to the online and consumers who read online reviews to their decision making to buy a product is the universe for the study. Considering the reasons of time and cost a sample of 104 is drawn as a sub-set of representative to the entire population through a Non-Probabilistic Sampling Technique and Convenient Sampling is used. The questionnaire was distributed to 200 participants but only 133 responded back. In 29 questionnaires, few columns were 
found incomplete, so researchers removed it from the sample. The gender demarcation of the participants of this survey is 57 males and 47 females. 59 of them are less than 30 years. 49 of them are post graduates/ professionally qualified. They could have also be part of any online communities such as social networking medium like LinkedIn and Face book. The present sample consumers use online reviews mostly in deciding to buy the following product or service.

- $\quad$ Consumer electronics

- Gadgets

- $\quad$ Mobile apps

- $\quad$ Gaming

- $\quad$ Entertainment - music and movie reviews

- $\quad$ Automobile

- Cosmetics

- $\quad$ Food / restaurants/cafe

- Hotels

- $\quad$ Mobile phone

- Local Service providers like car dealer/agency/tuition/ health instructors/clinics etc,

\section{Analysis, findings and interpretation} correlations.

The analysis was conducted through mean, one sample t-test, Factor analysis, F-test and

\section{a. Mean Scores}

To understand the overall opinion of the sample on the parameters of search for online reviews statement wise mean scores are calculated.

Table No: 1 Parameters on which consumers use online reviews to make decisions for buying a product or service

\begin{tabular}{|l|l|l|}
\hline \multicolumn{1}{|c|}{ Parameters } & Mean & Std. Deviation \\
\hline Ensure quality & 3.3365 & 1.25110 \\
\hline Information on product usage & 3.4231 & 1.24395 \\
\hline $\begin{array}{l}\text { Understand utilitarian or cost benefit analysis from peer } \\
\text { consumers }\end{array}$ & 3.4712 & 1.29942 \\
\hline Gather more information on similar products & 3.0769 & 1.46607 \\
\hline Understand the best deal & 3.3942 & 1.25735 \\
\hline Purchase a new product consumer not familiar & 3.0673 & 1.39531 \\
\hline Verify similar experience & 3.1923 & 1.28529 \\
\hline Price/ Value of detail in the review & 3.4423 & 1.22931 \\
\hline Sales service availability & 3.5288 & 1.14872 \\
\hline Prevent the decision of wrong buy & 3.1827 & 1.33485 \\
\hline Engage in sites for learning from reviews & 3.2308 & 1.26361 \\
\hline Brand reputation among reviewers & 3.3846 & 1.23310 \\
\hline Explore the logistic service & 3.5096 & 1.23064 \\
\hline Viewing the real pictures of the product or service & 3.1731 & 1.32520 \\
\hline Cumulative reviews posted by consumers & 3.5962 & 1.38311 \\
\hline Replacements and warranty or guarantees & 3.4038 & 1.31842 \\
\hline
\end{tabular}

It can be understood from the mean score for cumulative reviews posted online by reviewers is 3.59, which shows that majority of the consumers use cumulative reviews from the online reviews 
they visit to buy product or service. Other parameters on which consumers view online reviews are information (3.42), cost benefit of the product (3.44), information relevant to deals or discounts (3.39), explore logistic service information related to delivery / availability of the product (3.5) and product information on warranty or guarantee (3.4) details. It should be observed that for all the variables the scores are almost more than 3.00 in the mean value. This shows consumers at least rare cases use online reviews to decide on purchase. Following perceptions on variables such as Purchase a new product consumer not familiar (3.06), Gather more information on similar products (3.07) and prevent a wrong buy (3.18) brings out evidences that rarely or seldom consumers use online reviews to search such information.

\section{b. One sample T-Test}

One sample $\mathrm{T}$ test is attempted to understand whether most of the parameters on which the sample consumers use online reviews to make decisions for buying a product or service are same as those used by the overall population.

H1: Consumers use certain parameters of online reviews content on which consumer make buying decisions of a product or service

Table no: 2 One sample T-test for parameters on which consumers use online reviews to make decisions for buying a product or service

\begin{tabular}{|c|c|c|c|c|c|c|c|}
\hline \multicolumn{7}{|l|}{ One-Sample Test } & \multirow[b]{3}{*}{ Inference } \\
\hline & \multicolumn{6}{|c|}{ Test Value $=3$} & \\
\hline & \multirow[b]{2}{*}{$\mathrm{t}$} & \multirow[b]{2}{*}{$\mathrm{df}$} & \multirow{2}{*}{$\begin{array}{l}\text { Sig. } \\
(2- \\
\text { tailed) }\end{array}$} & \multirow{2}{*}{$\begin{array}{l}\text { Mean } \\
\text { Difference }\end{array}$} & \multicolumn{2}{|c|}{$\begin{array}{l}\text { 95\% Confidence } \\
\text { Interval of the } \\
\text { Difference }\end{array}$} & \\
\hline & & & & & Lower & Upper & \\
\hline Ensure quality & 2.743 & 103 & .007 & .33654 & .0932 & .5798 & Highly Significant \\
\hline $\begin{array}{l}\text { Information on } \\
\text { product usage }\end{array}$ & 3.468 & 103 & .001 & .42308 & .1812 & .6650 & Highly Significant \\
\hline $\begin{array}{l}\text { Understand cost } \\
\text { benefit analysis } \\
\text { from peer } \\
\text { consumers }\end{array}$ & 3.698 & 103 & .000 & .47115 & .2184 & .7239 & Highly Significant \\
\hline $\begin{array}{l}\text { Gather more } \\
\text { information }\end{array}$ & .535 & 103 & .594 & .07692 & -.2082 & .3620 & Not Significant \\
\hline $\begin{array}{l}\text { Understand the } \\
\text { best deal }\end{array}$ & 3.197 & 103 & .002 & .39423 & .1497 & .6388 & Highly Significant \\
\hline $\begin{array}{l}\text { Purchase a new } \\
\text { product } \\
\text { consumer not } \\
\text { familiar }\end{array}$ & .492 & 103 & .624 & .06731 & -.2040 & .3387 & Not Significant \\
\hline $\begin{array}{l}\text { Verify similar } \\
\text { experience }\end{array}$ & 1.526 & 103 & .130 & .19231 & -.0576 & .4423 & Not Significant \\
\hline $\begin{array}{l}\text { Price/ Value of } \\
\text { detail in the } \\
\text { review }\end{array}$ & 3.669 & 103 & .000 & .44231 & .2032 & .6814 & Highly Significant \\
\hline $\begin{array}{l}\text { Sales service } \\
\text { availability }\end{array}$ & 4.695 & 103 & .000 & .52885 & .3054 & .7522 & Highly Significant \\
\hline $\begin{array}{l}\text { Prevent the } \\
\text { decision of } \\
\text { wrong buy }\end{array}$ & 1.396 & 103 & .166 & .18269 & -.0769 & .4423 & Not Significant \\
\hline
\end{tabular}




\begin{tabular}{|l|l|l|l|l|l|l|l|}
\hline $\begin{array}{l}\text { Engage in sites } \\
\text { for learning from } \\
\text { reviews }\end{array}$ & 1.862 & 103 & .065 & .23077 & -.0150 & .4765 & Significant \\
\hline $\begin{array}{l}\text { Brand reputation } \\
\text { among reviewers }\end{array}$ & 3.181 & 103 & .002 & .38462 & .1448 & .6244 & Highly Significant \\
\hline $\begin{array}{l}\text { Explore the } \\
\text { logistic service }\end{array}$ & 4.223 & 103 & .000 & .50962 & .2703 & .7489 & $\begin{array}{l}\text { Highly } \\
\text { Significant }\end{array}$ \\
\hline $\begin{array}{l}\text { Viewing the real } \\
\text { pictures of the } \\
\text { product or } \\
\text { service }\end{array}$ & 1.332 & 103 & .186 & .17308 & -.0846 & .4308 & Not Significant \\
\hline $\begin{array}{l}\text { Cumulative } \\
\text { reviews posted } \\
\text { by consumers }\end{array}$ & 4.396 & 103 & .000 & .59615 & .3272 & .8651 & Highly Significant \\
\hline $\begin{array}{l}\text { Replacements } \\
\text { and warranty or } \\
\text { guarantees }\end{array}$ & 3.124 & 103 & .002 & .40385 & .1474 & .6602 & Highly Significant \\
\hline
\end{tabular}

The overall population mean and the sample mean perceives same on the following parameters used by consumers reading online reviews- gather more information on deciding to buy between similar products or services, purchase a new product consumer not familiar, verify similar experience, prevent the decision of wrong buy, engage in sites or online communities as part of admiration or learning from reviews, explore the logistic service and viewing the real pictures of the product or service. Hence for the above parameters the null hypothesis is accepted. For the following parameters on which consumers view online reviews such as understanding quality of the product, product usage information, cost benefit of the product , information relevant to deals or discounts , and product information on warranty or guarantee or replacement details, brand reputation among reviewers, sales service availability the $\mathrm{p}<0.05$, null hypothesis rejected which shows that consumers tend to perceive differently on these dimensions while using online reviews for deciding to buy any product or service.

\section{c. Factor Analysis}

Factor analysis is a technique attempted to reduce the number of variables into new set factors based on the relationships in the correlation matrix.

Table 3: Adequacy of data for Factor analysis-parameters on which consumers use online reviews to make decisions for buying a product or service

KMO and Bartlett's Test

\begin{tabular}{|l|l|l|}
\hline \multicolumn{2}{|l|}{ Kaiser-Meyer-Olkin Measure of Sampling Adequacy. } & .831 \\
\hline Bartlett's Test of Sphericity & $\begin{array}{l}\text { Approx. Chi- } \\
\text { Square }\end{array}$ & 714.364 \\
\cline { 2 - 3 } & df & 120 \\
\cline { 2 - 3 } & Sig. & .000 \\
\hline
\end{tabular}

The Table 3 above states that KMO Value is $>0.50$, and Bartlett's Test of Sphericity $-\mathrm{p}<0.05$ which proves sampling adequacy and the data can be used for conducting factor analysis.

\begin{tabular}{|l|c|c|}
\hline \multicolumn{3}{|c|}{ Table 4: Communalities } \\
\hline & Initial & Extraction \\
\hline Ensure quality & 1.000 & .674 \\
\hline Information on product usage & 1.000 & .802 \\
\hline
\end{tabular}

www.jbrmr.com A Journal of the Academy of Business and Retail Management (ABRM) 


\begin{tabular}{|l|c|c|}
\hline $\begin{array}{l}\text { Understand utilitarian or cost benefit } \\
\text { analysis from peer consumers }\end{array}$ & 1.000 & .702 \\
\hline $\begin{array}{l}\text { Gather more information on deciding to } \\
\text { buy between similar products or } \\
\text { services }\end{array}$ & 1.000 & .693 \\
\hline Understand the best deal & 1.000 & .642 \\
\hline $\begin{array}{l}\text { Purchase a new product consumer not } \\
\text { familiar. }\end{array}$ & 1.000 & .653 \\
\hline Verify similar experience & 1.000 & .577 \\
\hline Price/ Value of detail in the review & 1.000 & .720 \\
\hline Sales service availability & 1.000 & .521 \\
\hline Prevent the decision of wrong buy & 1.000 & .581 \\
\hline $\begin{array}{l}\text { Engage in sites for learning from } \\
\text { reviews }\end{array}$ & 1.000 & .584 \\
\hline Brand reputation among reviewers & 1.000 & .580 \\
\hline Explore the logistic service & 1.000 & .504 \\
\hline $\begin{array}{l}\text { Viewing the real pictures of the product } \\
\text { or service }\end{array}$ & 1.000 & .649 \\
\hline $\begin{array}{l}\text { Cumulative reviews posted by } \\
\text { consumers }\end{array}$ & 1.000 & .734 \\
\hline $\begin{array}{l}\text { Replacements and warranty or } \\
\text { guarantees }\end{array}$ & 1.000 & .753 \\
\hline Extraction Method: Principal Component Analysis. \\
\hline
\end{tabular}

The communalities mentioned in table 4 shows the strength of the variable to the construct developed on parameters on which consumers use online reviews to make decisions for buying a product or service.

Table 5: Total Variance Explained

\begin{tabular}{|c|c|c|c|c|c|c|}
\hline \multirow{2}{*}{ Component } & \multicolumn{4}{|l|}{ Initial Eigenvalues } & \multicolumn{3}{l|}{ Extraction Sums of Squared Loadings } \\
\cline { 2 - 7 } & Total & \% of Variance & Cumulative \% & Total & \% of Variance & Cumulative \% \\
\hline 1 & 6.031 & 37.695 & 37.695 & 6.031 & 37.695 & 37.695 \\
\hline 2 & 1.806 & 11.287 & 48.982 & 1.806 & 11.287 & 48.982 \\
\hline 3 & 1.423 & 8.891 & 57.873 & 1.423 & 8.891 & 57.873 \\
\hline 4 & 1.009 & 6.307 & 64.180 & 1.009 & 6.307 & 64.180 \\
\hline 5 & .910 & 5.689 & 69.869 & & & \\
\hline 6 & .728 & 4.551 & 74.420 & & & \\
\hline 7 & .700 & 4.374 & 78.793 & & & \\
\hline 8 & .602 & 3.764 & 82.557 & & & \\
\hline 9 & .553 & 3.459 & 86.017 & & & \\
\hline 10 & .461 & 2.883 & 88.899 & & & \\
\hline 11 & .380 & 2.372 & 91.271 & & & \\
\hline 12 & .358 & 2.238 & 93.510 & & & \\
\hline 13 & .350 & 2.186 & 95.696 & & & \\
\hline 14 & .272 & 1.700 & 97.396 & & & \\
\hline 15 & .214 & 1.336 & 98.732 & & & \\
\hline 16 & .203 & 1.268 & 100.000 & & & \\
\hline
\end{tabular}

Extraction Method: Principal Component Analysis.

The total variance explained through factor analysis (principal component analysis) is $64 \%$, which explains that the construct measure the objectives designed and delineated by the variables. 
Table 6: Rotated Component Matrix

\begin{tabular}{|l|c|c|c|c|}
\hline & \multicolumn{3}{|c|}{ Component } \\
\cline { 2 - 5 } & 1 & 2 & 3 & 4 \\
\hline Ensure quality of the product or service & & .724 & & \\
\hline Information on product usage & & .807 & & \\
\hline $\begin{array}{l}\text { Understand utilitarian or cost benefit analysis from peer } \\
\text { consumers }\end{array}$ & & .720 & & \\
\hline $\begin{array}{l}\text { Gather more information on deciding to buy between } \\
\text { similar products or services }\end{array}$ & & & & .703 \\
\hline $\begin{array}{l}\text { Understand the best deal available or reward } \\
\text { points/discounts }\end{array}$ & & .670 & & \\
\hline $\begin{array}{l}\text { Purchase a new product from a brand with which } \\
\text { consumer not familiar. }\end{array}$ & & & & .693 \\
\hline $\begin{array}{l}\text { Verify similar experience in the product or service usage } \\
\text { Price/ Value or Amount of detail in the review }\end{array}$ & & & .705 & \\
\hline Understand after sales service availability & & & .536 & \\
\hline $\begin{array}{l}\text { Check online review as part to prevent the decision of } \\
\text { wrong buy }\end{array}$ & & & .583 & \\
\hline $\begin{array}{l}\text { Engage in sites or online communities as part of } \\
\text { admiration or learning from reviews }\end{array}$ & & & & .515 \\
\hline Understand the brand reputation among reviewers & .645 & & & \\
\hline $\begin{array}{l}\text { Explore the logistic service in terms of delivery of the } \\
\text { product etc., }\end{array}$ & & & & .516 \\
\hline $\begin{array}{l}\text { Viewing the real pictures of the product or service to } \\
\text { capture the quality, color etc., as posted by consumers in } \\
\text { the content }\end{array}$ & .765 & & & \\
\hline $\begin{array}{l}\text { Identify and analyze the cumulative reviews posted by } \\
\text { consumers }\end{array}$ & .845 & & & \\
\hline $\begin{array}{l}\text { Read comments on Replacements and warranty or } \\
\text { guarantees are honored }\end{array}$ & .814 & & & \\
\hline
\end{tabular}

Extraction Method: Principal Component Analysis.

Rotation Method: Varimax with Kaiser Normalization.

a. Rotation converged in 6 iterations.

There are four factors that emerged from the research study.

Factor 1- Rating and Reality check

The factor 1 is named as 'Rating and Reality check' because consumers look forward for real product details, cumulative ratings and understand about the brand. They are the real picture and hence named as reality check.

\section{Factor 2- WIIFM principle}

This factor is named as what is in for me and the Acronym is WIIFM principle. This explains the expectations of the consumer on the online content such as product benefit, deals etc.

\section{Factor 3- Syndrome 'Beware'}

The general attitude of consumer is not doing a wrong buy and Verify similar experience in the product or service usage. Most of the variables grouped under the category relate to cautious syndrome of the consumer before deciding to buy a product or service.

\section{Factor 4- Inquisitive orientation}

As a consumer, most of them are interested to gain information of product and service. This learning helps them to understand features of new products or gain comparative analysis of products. 


\section{d. One way ANOVA}

A F-test has been performed to understand the significant gender wise differences on the factors, which consumers use online reviews to make decisions for buying a product or service is given in the table below.

Table 7: One way ANOVA

\begin{tabular}{|c|c|c|c|c|c|c|}
\hline & & $\begin{array}{l}\text { Sum of } \\
\text { Squares }\end{array}$ & $\begin{array}{l}\text { Mean } \\
\text { Square }\end{array}$ & $\mathrm{F}$ & Sig. & Inference \\
\hline \multirow{2}{*}{$\begin{array}{l}\text { Rating and } \\
\text { Reality check }\end{array}$} & \begin{tabular}{|l|} 
Between \\
Groups
\end{tabular} & 72.907 & 72.907 & 3.975 & .049 & \multirow[t]{2}{*}{ Highly significant difference } \\
\hline & $\begin{array}{l}\text { Within } \\
\text { Groups }\end{array}$ & 1870.622 & 18.339 & & & \\
\hline \multirow{2}{*}{$\begin{array}{l}\text { WIIFM } \\
\text { principle }\end{array}$} & \begin{tabular}{|l|} 
Between \\
Groups
\end{tabular} & 7.207 & 7.207 & .452 & .503 & \multirow[t]{2}{*}{ No significant difference } \\
\hline & $\begin{array}{l}\text { Within } \\
\text { Groups }\end{array}$ & 1627.168 & 15.953 & & & \\
\hline \multirow{2}{*}{$\begin{array}{l}\text { Syndrome } \\
\text { 'Beware' }\end{array}$} & $\begin{array}{l}\text { Between } \\
\text { Groups }\end{array}$ & .003 & .003 & .000 & .989 & \multirow[t]{2}{*}{ No significant difference } \\
\hline & \begin{tabular}{|l|} 
Within \\
Groups \\
\end{tabular} & 1453.536 & 14.250 & & & \\
\hline \multirow{2}{*}{$\begin{array}{l}\text { Inquisitive } \\
\text { orientation }\end{array}$} & $\begin{array}{l}\text { Between } \\
\text { Groups }\end{array}$ & 51.501 & 51.501 & 3.395 & .068 & \multirow[t]{2}{*}{ No significant difference } \\
\hline & $\begin{array}{l}\text { Within } \\
\text { Groups }\end{array}$ & 1547.115 & 15.168 & & & \\
\hline
\end{tabular}

It can be observed that man and women think differently on Rating and Reality check. Whereas in the remaining three factors there is no effect of gender.

\section{Correlations}

To understand the relationship between stimulus and response, an attempt has been made to conduct Pearson's correlation (Table 8).

Table 8: Relationship between parameters on which consumers use online reviews for buying a product or service with the response for deciding to buy

\begin{tabular}{|l|l|l|l|}
\hline \multicolumn{2}{|c|}{} & $\begin{array}{l}\text { Parameters of Online } \\
\text { Review Content }\end{array}$ & $\begin{array}{l}\text { Decision to } \\
\text { buy }\end{array}$ \\
\hline $\begin{array}{l}\text { Parameters of } \\
\text { Online Review } \\
\text { Content }\end{array}$ & $\begin{array}{l}\text { Pearson } \\
\text { Correlation }\end{array}$ & 1 & .138 \\
\cline { 2 - 4 } & Sig. (2-tailed) & & .003 \\
\cline { 2 - 4 } & $\mathrm{N}$ & 104 & 104 \\
\hline Decision to buy & $\begin{array}{l}\text { Pearson } \\
\text { Correlation }\end{array}$ & .138 & 1 \\
\cline { 2 - 4 } & Sig. (2-tailed) & .003 & 104 \\
\cline { 2 - 4 } & $\mathrm{N}$ & 104 & \\
\hline @ 5\% level of Sig & & & \\
\hline
\end{tabular}

\section{Interpretation}

From the table above it can be observed that at 5\% level of significance there is significant positive relationship between parameters on which consumers use online reviews for buying a product or service with the response for deciding to buy. The correlation value is 0.138 
which shows there is no strong relationship. This confirms that the online review content affects the buying decision to some extent.

\section{Conclusion and managerial implications}

The study revealed by mean score that that majority of the consumers use cumulative reviews from the online reviews they visit to buy product or service. More the number of similarity in content they believe in it. Other parameters on which consumers view online reviews are information, cost benefit of the product, information relevant to deals or discounts, explore logistic service information related to delivery / availability of the product and product information on warranty or guarantee details.

The one sample t-test identified that consumers view online reviews such as understanding quality of the product, product usage information, cost benefit of the product, information relevant to deals or discounts, and product information on warranty or guarantee or replacement details, Brand reputation among reviewers, Sales service availability for deciding to buy.

Factor analysis conducted to reduce the parameters on which consumers use online reviews to make decisions for buying a product or service revealed four factors that organizations must considered in managing online reviews. They are Rating and Reality check, WIIFM principle, Syndrome 'Beware' and Inquisitive orientation. In addition, for the category of on which most of the online reviews are commonly used to buy product or service, it was found that for mobile apps, to gain information related to automobiles and restaurants.

Management responses to online reviews are becoming an increasingly important reputation management strategy. Most previous studies involving online word-of-mouth have found a positive relationship between and sales. However, the present study intended to understand the online generated reviews. On examining the research framework following are the implications that organizations must consider while managing the online reviews-

- Making detailed information about products available and easily accessible.

- Establishing brand communities and early adopter clubs. Members of these clubs can buy products with incentives before launch to spark the feedback process. This is because positive experiences or negative experiences shared in the portal have revealed relationship for decision to buy a product.

- To add further companies can use positive feedback as seeds and negative feedback to modify their products before launch.

- Online copies of terms and conditions can be made available in the company website or the retailers, as most of them had revealed that they search information in online reviews for the same.

- Demo videos for defending negative ratings can be a technique to manage reviews, hospitality industry uses it as virtual tour.

- As inquisitive learner's consumers read reviews. So, online reviews must be monitored to value add details to product. Companies most demonstrate their reactiveness to receive feedback and reply for queries.

- A wrong buy is always avoided by a consumer. This evidence from the study indicates that any e-com/ m-com must be supported by a human interface such as customer service executives etc.

\section{Limitations}

The present study is based on the perception of the consumers on online reviews and hence the opinion of the respondents cannot be extrapolated. Time is a constraint and the primary data is collected from tool that is not validated with convenient sample methodology. The findings and conclusions are indicative framework. 


\section{Future scope of study}

The present study can be extended to understand the impact of reviews in creating stronger or weaker brands. Researchers can explore variables such as constructive feedback and repurchase as part of buying decisions based on online review management.

\section{References}

Arndt, J. (1967) Role of product-related conversations in the diffusion of a new product. Journal of Marketing Research 4, 291-5.

Bickart, Barbara and Robert M. Schindler (2001), "Internet Forums as Influential Sources of Consumer Information," Journal of Interactive Marketing, 15(3), 31-40.

Chen, Stephen (2001), "Assessing the Impact of the Internet on Brands," Journal of Brand Management, 8(4-5), 288-295

Cheung Christy M.K., Lei Zhu, Timothy Kwong, Gloria W.W. Chan, MoezLimayem, (2003) Online Consumer Behavior: A Review and Agenda for Future Research, 16th Bled eCommerce Conference eTransformation.

Chris Forman and Anindya Ghose, Batia (2008). Examining the Relationship Between Reviews and Sales: The Role of Reviewer Identity Disclosure in Electronic Markets, Information Systems Research, Vol. 19, No. 3, pp. 291-313.

Dabholkar, P. 2006. "Factors Influencing Consumer Choice of a 'Rating Web Site': An Experimental Investigation of an Online Interactive Decision Aid," Journal of Marketing Theory and Practice (14:4), pp. 259-273.

Gopinath, S., P.K. Chintagunta, S. Venkataraman. 2013. Blogs, advertising and local-market movie boxoffice performance, Management Science (Articles in Advance) 1-20.

Hansen, T. (2005). Perspectives on Consumer Decision Making: an Integrated Approach. Journal of Consumer Behaviour, 4(6), 420-437.

J. A. Chevalier and D. Mayzlin (2006). "The effect of word of mouth on sales: Online book reviews", Journal of Marketing Research, vol. 43, no. 3, pp. 345-354.

Jiang, Z., and Benbasat, I. 2007. "Investigating the Influence of the Functional Mechanisms of Online Product Presentations," Information Systems Research (18:4), pp. 221-244.

Kumar, N., and Benbasat, I. 2006. "The Influence of Recommendations on Consumer Reviews on Evaluations of Websites," Information Systems Research (17:4), pp. 425-439.

Liu, Y. 2006. Word-of-mouth for movies: Its dynamics and impact on box office revenue. Journal of Marketing 70(3) 74-89.

Luca, Michael, Georgios Zervas. 2015. Fake it till you make it: Reputation, competition, and yelp review fraud. Management Science, Forthcoming.

Mudambi\&Schuff (2010). Consumer Reviews on Amazon.com, MIS Quarterly Vol. 34 No. 1, pp. 1852000.

N. Hu, L. Liu, and J. Zhang (2008). “Do online reviews affect product sales? The role of reviewer characteristics and temporal effects", Information Technology \& Management, vol. 9, no. 3, pp. 201-214.

Nga N. Ho-Dac, Stephen J. Carson, and William L. Moore (2013). The effects of positive and negative online customer reviews: do brand strength and category maturity matter? Journal of Marketing, American Marketing Association, preprint version.

P. Chatterjee, (2000). "Online reviews: Do consumers use them?", Advances in Consumer Research, vol. 28 , no. 1 , pp. 129-133

P. J. Sher and S. Lee, (2009). “Consumer skepticism and online reviews: An elaboration likelihood model perspective", Social Behavior and Personality, vol. 37, no. 1, pp. 137-144.

P. Resnick, R. Zeckhauser, E. Friedman, K. Kuwabara (2000). “Reputation systems” Communications of the ACM, vol. 43, no. 12, pp. 45-48. 
Pride, W. M., Ferrell, O. C. (2007). Foundations of Marketing (2nd ed.). Boston, MA: Houghton Miffin Company.

Riegner C, (2007). Word of mouth on the web: The impact of web 2.0 on consumer purchase decisions, Journal of advertising research. VOL 47(4). 436-447.

Shih Yung Chou (2012). Online Reviews and Pre-Purchase Cognitive Dissonance: A Theoretical Framework and Research Propositions, Journal of Emerging Trends in Computing and Information Sciences, VOL. 3, NO. 2.

Sonnier, G.P., L. McAlister, O.J. Rutz, (2011). A dynamic model of the effect of online communications on firm sales. Marketing Science 30(4) 702-716.

Y. Chen and J. Xie (2008). "Online consumer review: wordof-mouth as a new element of marketing communication mix", Management Science, vol. 54, no. 3, pp. 477-491.

Zan Mo, Yan-Fei Li, Peng Fan (2015). Effect of Online Reviews on Consumer Purchase Behaviour, Journal of Service Science and Management, Vol: 8, 419-424. 